\title{
The Rights of Children of Imprisoned Parents
}

\section{Introduction and Context}

Children of imprisoned parents are being recognised increasingly as rights-bearers, at least in academic and practitioner research publications. This builds on the substantial existing jurisprudential framework of prisoners' rights and children's rights which exists in many countries and which has evolved to include and reflect international treaties and conventions and also domestic legal principles. The children of prisoners may possess human rights emanating from international treaty obligations, combined with specific rights as children and, depending on the nature of the offence, as victims. Such rights may be granted explicitly via constitutional provisions, or statutes, or may be introduced and maintained by means of case law and innovative judicial interpretation of existing international and domestic legal obligations. An emergent body of published research literature has explored the nature, scope, applicability and operation of such rights in relation to specific categories of prisoners' children including babies, children residing in prisons with their parents, and children separated from parents due to their incarceration. That said, rights discourse itself has been criticised in this context and some commentators argue for a conception of duties and responsibilities towards children rather than children's rights. There is, in addition, a real gap between theoretical and aspirational rights for children, as emanating from international and domestic legal provisions and obligations, and practical and enforceable children's rights.

This chapter outlines key sources of rights for children of incarcerated parents, including international treaty obligations, state constitutional principles and domestic legislation, and then explores two key issues which illustrate the opportunities and challenges for legislators, policy-makers and the judiciary posed by a commitment to recognising and implementing 
children's rights i.e. first, children's rights when a court is considering imposing a custodial sentence on a parent, and, second, the specific issues raised when considering whether a child should reside with a parent in a custodial setting. In particular, the chapter will consider the significance of the United Nations Convention on the Rights of the Child (UNCRC), the European Convention on Human Rights (ECHR) and the African Charter on the Rights and Welfare of the Child. The African Charter is particularly significant as, along with the South African Constitution, it has influenced the South African Constitutional Court in prioritising children's rights at the point of the decision whether or not to impose a custodial sentence on their primary caregiver. It is thus valuable in illustrating how the rights of children of convicted offenders can be prioritised, protected and promoted. The chapter concludes with a discussion of good practice in promoting and protecting the rights of children with incarcerated parents, questioning the limitations of rights-based approaches in themselves.

\section{Sources of Rights for Children of Incarcerated Parents}

\section{International Obligations}

Identifying the rights of prisoners' children is, on the whole, no easy task. Prisoners' children are not recognised generally as a specific group, but may be served by rights under other legal provisions which, for example relate to prison rules, rules for imprisoned women and mothers, and general human rights provisions. In some jurisdictions, such as South Africa, constitutional provisions relating to the wellbeing of all children can provide valuable safeguards for the rights of children whose parents are incarcerated. In other countries, the provisions of the United Nations Convention on the Rights of the Child (UNCRC) 1989 have 
been incorporated into domestic legislation, along with accessible enforcement mechanisms. In European countries which are signatories to the European Convention on Human Rights (ECHR) 1950, provisions such as Article 8 can offer fertile ground for legal challenges based around the qualified right to family life, which applies to both adults and children. However, identifying the actual rights prisoners' children possess can be difficult, and there is also the thorny question of whether these rights can be maintained in practical terms, especially as children are vulnerable and may often not have the ability or facilities to access legal services to challenge and fight for these rights.

\section{The Role of the UN}

At the international level, several bodies of the United Nations have stressed the need to address the needs of the children of prisoners, taking into account their human rights, as in the Salvador Declaration of the $12^{\text {th }}$ UN Crime Congress (Salvador Declaration on Comprehensive Strategies for Global Challenges: Crime Prevention and Criminal Justice Systems and their Development in a Changing World 2010). In addition, the Bangkok Rules, supplementing the Standard Minimum Rules for the Treatment of Prisoners, while focusing on women, contain rules requiring consideration of the best interests of the child. This is also recognised in the UN Model Strategies and Practical Measures on the Elimination of Violence against Women in the Field of Crime Prevention and Criminal Justice (2014), which extends the protections outlined in the model strategies to include the children of incarcerated parents, who are recognised as falling within the definition of "children in contact with the justice system". 
The most significant international obligations that focus on children are those under the United Nations Convention on the Rights of the Child 1989 (UNCRC). This convention does not make specific reference to children affected by parental imprisonment, but it is holistic in its approach which means that it contains protections for prisoners' children which have been described as "ample" (Donson \& Parkes, 2016). Significantly, however, the US is not a signatory to the convention although all other UN member countries are. The Convention has four guiding principles which must be read alongside each of the other provisions. Thus the key principles are non-discrimination (Article 2); the best interests of the child (Article 3); the right of the child to life, survival and development (Article 6) and the right of the child to express their views (Article 12). Article 12 sets out that once a child is capable of forming views, the child has a right to express those views on all matters affecting him or her, with due weight being accorded to those views in accordance with the age and maturity of the child. Article 3 provides that in all matters concerning children undertaken by courts of law "the best interests of the child shall be a primary consideration."

There are also specific provisions which are relevant to the children of prisoners, including Articles 9(1) and 9(3) which set out that children should not be separated from their parents except where it is necessary to ensure their best interests are protected, and where they are separated then it is vital that they maintain direct and personal contact with both parents on a regular basis. Articles 13 and 17 protect children's rights to information. Subsequent to the Convention itself, the UN Committee on the Rights of the Child (CRC) has set out that these best interests assessments should be incorporated into multiple aspects of the criminal justice process as experienced by prisoners' children, including arrest and detention; sentencing; the decision as to whether a child should live in the prison with their caregiver, nd decisions about removing State support from the child or the carer (Townhead 2015). NGOs have made, and 
continue to make, highly significant contributions to UN policy-making: one of the most visible being the Quaker United Nations Office (QUNO) which, through publications and direct contributions to UN policy-making, has led the way in identifying and publicising global perspectives on a range of issues relating to the children of incarcerated parents, including issues arising parents are arrested when children are present; the bail/remand decision; the sentencing stage (including the death penalty), and then questions of the environment/prison in which the sentence is served, including visitation rights, provision for parent-child contact, then planning for release and subsequent resettlement (Robertson: 2007: Townhead 2015: Alejos 2005: Robertson, 2012). ${ }^{i}$

The CRC has signalled its commitment to promoting and maintaining the wellbeing of prisoners children, holding a Day of General Discussion on 30 September 2011. This has prompted the development and publication of guidelines on diverse aspects of the impacts of criminal justice processes on children, such as relating to parental arrest and detention; mothers/babies and children incarcerated with their parents, and further exploration of relevant issues (UNCRC, 2011) . Following on from the Day of General Discussion in 2011, the CRC has continued to demonstrate an interest and commitment to the rights of children affected by parental imprisonment in its concluding observations. However, as Fortin (2014) points out, the UNCRC has always had two major weaknesses. First, many of the rights enshrined within it are only aspirational and second, the absence of any direct method of formal enforcement. There has, for example, never been a court attached to the UNCRC which could assess claims of infringements of convention provisions. The Third Optional Protocol to the Convention on the Rights of the Child came into force on 14 April 2014, providing children or their representatives with the opportunity to access justice at the 
international level, but children are only able to use this complaints procedure if their State has ratified this Optional Protocol, and to date most countries, including the UK, have not ${ }^{\mathrm{ii}}$

\section{The African Charter on the Rights and Welfare of the Child}

There are other relevant international obligations which apply to particular regions, one of the most relevant in this context being the African Charter on the Rights and Welfare of the Child. This charter is unusual in that it not only echoes the language of the CRC in establishing the "best interests" standard, and provides for children's views to be heard but it addresses specifically children with incarcerated mothers. The Charter requires parties "to provide special treatment to expectant mothers and to mothers of infants and young children" when convicted of criminal offences, and to "ensure that a non-custodial sentence will always be first considered when sentencing such mothers." This article requires parties also to establish and promote alternatives to institutional confinement, and prohibits the death penalty for mothers. Boudin (2011) criticises this focus on mothers as 'troubling' (p.86) but recognises that the reality of child-rearing means that the responsibility for child-rearing usually falls on mothers. This approach is unsurprising, but does not recognise the role of fathers in child development and childcare, and, again unsurprisingly, does not recognise the nuances of parenting in LGBTQI+ contexts, or contexts around assisted reproduction where a binary categorisation of a parent as simply 'mother' or 'father' is inadequate.

\section{The European Convention on Human Rights}

In Europe prisoners' rights litigation under the ECHR has a long history (van Zyl Smit \& Snacken, 2009). In the UK, rights claims by prisoners under the ECHR has been enabled most recently by the access to justice prompted by the Human Rights Act 1998, which made the 
ECHR actionable in the domestic courts. It could be argued that in the UK the CRC has been less significant as a route for maintaining the rights of children of prisoners than the ECHR, most obviously because, unlike the ECHR, there is no direct enforcement mechanism. Article 8 establishes a qualified right to private and family life, which allows for proportionate interference with the rights of private and family life on the basis of interests such as public health and morality, and Lyon (2007) argued that public bodies and organisations should focus on remedies being brought under the HRA and the ECHR rather than attempting to do so with reference to the UNCRC. The European Court of Human Rights has stated that this balancing of competing interests needs to include the best interests of the child (Johansen $v$ Norway [1996] ECHR 31). The qualified nature of the rights under Article 8 means that public safety and protection, including security, can be utilised as justifications for interference with rights, which can have a direct impact on prisoners' children. This approach can be seen, for example, where security is used to justify restricting parent-child contact to 'closed' visits, even where this can cause distress and upset to the child who is unable to connect with their parent other than through glass (Codd, 2008).

At the time of writing, the UK government has committed to repealing the HRA and instead replacing these rights with a UK-specific Bill of Rights. This would not remove the relevance of the ECHR treaty obligations, but challenges could not be brought in the domestic courts. Litigation to date has explored issues including the rights of mothers of young children in relation to Mother and Baby units; rights to parental leave and costs of phone calls, but these actions have not been brought by or on on behalf of children themselves, even though they are equally protected as bearers of their own enforceable rights (Epstein 2014). Historically, rights-based litigation has focused on the rights of prisoners, rather than their children, and this is partly because of a core problem within the current structure of rights-based 
approaches which is dependent on actions being brought as a consequence of imfringement of rights, and also is a consequence of the UNCRC lacking an enforcement mechanism, unlike the ECHR.

\section{Domestic Constitutional Principles and Legislation as Sources of Rights for Children of Incarcerated Parents}

In some jurisdictions the rights of children with incarcerated parents are protected under the existing domestic constitution, or there is the potential to interpret constitutional provisions so as to promote and protect the wellbeing of prisoners children. Chesa Boudin (2011), himself the child of an imprisoned mother, reframes third party harms to children of prisoners and prison visitation policy in the US through the lens of children's rights rather than prisoners' rights, grounding this within children's constitutional rights of freedom of association under the First Amendment and due process liberty interests. Similarly, Kanaboshi et.al. (2017) have argued that babies' and toddlers' rights to develop secure attachment relationships with their mothers are protected under several amendments to the US Constitution. Boudin refers to the CRC, and UK case law, along with the $S \vee M$ case in South Africa and also the proposed Bill of Rights for Children of Incarcerated Parents propounded by the San Francisco Partnership for Incarcerated Parents (2003), arguing that many of these principles may have a legal basis in the existing US constitution. He also highlights good practice by individual state legislatures such as the state of New Jersey, which has passed several bills that together seek to reduce recidivism rates; protect children of prisoners and break the cycles of recidivism and intergenerational incarceration.

South Africa's Bill of Rights has been recognised internationally as a good example of constitutional provisions which protect and provide for the advancement of children's rights (Alston \& Tobin, 2005). A number of cases have been brought by children themselves and by 
organisations advocating for children's rights, as the Constitution takes a broad approach to interpreting whom is defined as having sufficient standing to bring cases (Skelton, 2015). In addition, where a genuine constitutional issue is at stake a litigant is not at risk of having a costs order made against them if their action is unsuccessful, and if successful they are entitled to be awarded costs. This approach is thus significant in promoting genuine challenges by and on behalf of children. Cases brought before the South African Constitutional Court have addressed a wide range of children's issues, including rights to education and sentencing decisions for young offenders. The Constitutional Court has often interpreted the rights under the constitution with reference to the African Charter on the Rights and Welfare of the Child (ACRWC) and the CRC, along with consideration of UN general comments, which, in the words of Skelton (2015) "gives South African child rights litigators a rich store-cupboard on which to draw."

There are some valuable examples of good practice in recognising the rights of prisoners' children in national law, especially in Scandinavia. In Norway, the prison law has established children's right to contact with their parents as a general principle, although children are never allowed to live with an imprisoned parent (Scharff Smith 2015). In Denmark, which shares a similar Scandinavian penological foundation, the prison law stipulates that children are only allowed to live in the prison with their parents if the conditions in the institution are suitable for children. In the UK, Wales has led the way in promoting the application of the principles of the CRC by passing the Rights of Children and Young People (Wales) Measure 2011 with cross-party unanimous support, which created a duty on Welsh Ministers to have regard to the CRC, the first legislature within the UK to do so. It remains to be seen, however, how much impact this Measure has in relation to children of incarcerated parents, although 
family-focused work at HMP Parc has been applauded as a beacon of good practice in helping maintain positive relationships between children and their imprisoned fathers, including a designated family interventions unit wing, and Parc Supporting Families (PSF) offering multiple interventions including parent-teacher evenings and parenting courses (Her Majesty's Inspectorate of Prisons, 2016).

\section{Recognising Children's Rights}

Although the rights of the children of incarcerated parents are relevant throughout the parent's journey through the criminal justice system, much of the research literature has discussed and analysed rights issues at either the point of sentence, or in relation to the question of whether children should live with their parent(s) in prison.

\section{Recognising the Rights of Children when Sentencing a Parent}

Debates around children's rights and parental imprisonment raise inevitable questions about whether courts should take into account the impact of imprisonment on the children of offenders at the point when they are being sentenced. Children are not by themselves parties to the criminal trial, as the trial itself engages in a binary manner with the offender and the state (Conway, 2010) and thus there is a significant question as to their status as third party actors and also, on a practical level, questions of appropriate mechanisms by which their interests could be articulated for consideration by the court (Donson \& Parkes, 2016). Where children are the victims of the offence, then depending on the jurisdiction their experiences and views can be introduced by means of a Victim Impact Statement. Where they are not the victim, then the amount of weight consideration of the impact on children of sentencing a 
parent to imprisonment varies from jurisdiction to jurisdiction (Minson, S. Nadin, R. \& Earle, J. 2015: Millar, H \& Dandurand, Y. 2017).

Evidence from the UK demonstrates that when deciding on a sentencing disposal, courts may regard responsibility for children as linked to the offender, for consideration as a form of mitigation (Donson \& Parkes, 2016). However, this form of personal mitigation is discretionary and is not rooted in consideration of the rights of children themselves: the focus is on the offender, and not on the interests of any children who might be affected by the sentence. Where this information is provided to the court, as mitigation, it may be presented by the solicitor or barrister for the defence, in mitigation, or as part of a pre-sentence report (in England \& Wales). In contrast with family cases involving children, in which a particular guardian is appointed to represent the interests of the child, there is no equivalent role in criminal trials in England \& Wales.

One might expect that the significant case of $R v$ Rosie Petherick [2012] EWCA Crim 2214 would have had an impact on the sentencing of mothers with dependent children in England and Wales. This Court of Appeal case built on previous cases in order to set out the approach to be taken by the court in balancing the sentencing process with the requirements under Article 8 of the ECHR. In this judgment the court recognised the interference posed by a prison sentence not only on the defendant but on other people including children. The court must therefore consider whether

i) there was any interference with family life in accordance with Article 8;

ii) that interference is in accordance with the law and in pursuit of a legitimate aim and 
iii) that this interference is proportionate, considering the balance between legitimate sentencing objectives on one hand and the Article 8 rights of dependent children on the other. The case made clear that the impact on children may make an apparently proportionate sentence disproportionate, and also clarified the place of the impact on children of claims concerning the right to life and mitigation, pointing out that where custody cannot proportionately be avoided, the impact on children may mitigate the length of sentence, but it also may not do so.

On paper, Petherick seems to provide a firm statement recognising the importance of considering the impact of imprisonment on family members including children. However, it has not led to a change in the mindset of sentencers. Epstein (2014) found, for example, that sentencers routinely failed to conduct this 'balancing act' and the impact on children is taken as part of a traditional mitigatory approach and not with reference to children's rights. This has been explained as being due to sentencers lacking information on which they could base this balancing act; lack of familiarity in lower courts with decisions of higher courts; concern aboiut perceived gender discrimination in favour of mothers and a concern that allowing recognition of children during the sentencing process could be seen as providing offenders with a 'get out of jail free' card (Minson, Nadin \& Earle, 2015).

One of the most significant judgements in relation to the rights of a child when a parent is being sentenced is the 2007 judgment of Albie Sachs in the case of M versus The State ([2007] ZACC 18), a case brought in South Africa which has become the subject of a great deal of international attention and which has been applauded for demonstrating how children's 
rights can be recognised and prioritised when deciding how to sentence a parent who is responsible for the care of dependent minor children.

The case, heard before the Constitutional Court of South Africa, assessed whether, when considering whether to impose imprisonment on the primary caregiver of young children, the lower courts paid sufficient attention to the constitutional provision that in all matters concerning children, the children's interests shall be paramount, as is enshrined in Section 28 of the South African Constitution, which provides that: "[a] child's best interests are of paramount importance in every matter concerning the child."

In this case, $M$ was a 36 year old single mother of three boys aged 16,12 and 8 , and who had been sentenced to imprisonment for fraud. The core issue at stake was the nature of the duties of the sentencing court in the light of section 28(2) of the Constitution, and any relevant statutory provisions, when the person being sentenced is the primary caregiver of minor children; whether these duties were observed in this case; and, if these duties were not observed, what order should the Court make, if any. It was contended by the applicant, the curator ad litem and the amicus curiae (from the Centre for Child Law of the University of Pretoria) that the effect of section 28 of the Constitution was to require sentencing courts, as a matter of general practice, to give specific and independent consideration to the impact that a custodial sentence in respect of a primary caregiver could have on minor children. They argued on the facts that due consideration of the interests of $\mathrm{M}^{\prime} \mathrm{s}$ children required that an appropriately stringent correctional supervision order should be imposed in place of a custodial sentence. In response the National Director of Public Prosecution argued that current sentencing procedures in the courts already took account of the interests of children and that on the facts of the case the decision of the High Court should not be interfered with, 
a similar position being adopted by Counsel for the Department of Social Development and the Department of Justice and Constitutional Development.

In his judgment Albie Sachs began by explaining the basis of sentencing decisions in South Africa, this framework predating democracy. This process, formulated in the case of $S v$ Zinn 1969 (2) SA 537 (A) and often referred to as 'the Zinn triad' set out that "What has to be considered is the triad consisting of the crime, the offender and the interests of society". Alongside this, in the $P$ case (see Director of Public Prosecutions, KwaZulu-Natal v $P$ (2006) 3 SA 515 (SCA) it was said that in the assessment of an appropriate sentence the court is required to have regard to the main purposes of punishment, namely its deterrent, preventive, reformative and retributive aspects, to which mercy, as distinct from mere sympathy, has to be added. Sachs also added that it was necessary to take account of the fact that the traditional aims of punishment had been transformed by the Constitution, and stressed the importance of courts paying due respect to children's rights, emphasising individual children as rights bearers:

"Every child has his or her own dignity. If a child is to be constitutionally imagined as an individual with a distinctive personality, and not merely as a miniature adult waiting to reach full size, he or she cannot be treated as a mere extension of his or her parents, umbilically destined to sink or swim with them. The unusually comprehensive and emancipatory character of section 28 presupposes that in our new dispensation the sins and traumas of fathers and mothers should not be visited on their children." (p.11)

In addition, he recognised that the paramountcy principle entails state actions not harming children further:

"No constitutional injunctions can and of itself isolate children from the shocks and perils of harsh family and neighbourhood environments. What the law can do is protect children from abuse and maximise opportunities for them to lead productive and happy lives. Thus, even if the state cannot itself repair disrupted family life, it can create positive conditions for repair to take place, and diligently seek where possible to avoid conduct of its agencies which may have the effect of placing children in peril. It follows that section 28 requires the law to make 
best efforts to avoid, where possible, any breakdown of family life or parental care that may threaten to put children at increased risk. Similarly, in situations where rupture of the family becomes inevitable, the State is obliged to minimise the consequent negative effect on children as far as it can."

In a previous case [Minister of Welfare and Population Development v. Fitzpatrick and Others 2000 (3) SA 422] this was spoken of as a right, not just a guiding principle, which Sachs stressed. He then discussed the appropriate approach to sentencing where the person convicted was the primary caregiver of minor children, noting that that what is important is the concept of primary caregivers, not that of breadwinners. Essentially, it is a question of caring responsibilities and activities, not money. Although Counsel for the State argued that sentencing courts already considered the circumstances of the criminal, the amicus curiae responded that "a child of a primary caregiver is not a "circumstance" but an individual whose interests need to be considered independently" (p.18).

Sachs went on to address arguments that parents may escape punishment, but points out that it is the imposition of the sentence without special regard for the children's interests which threatened to harm them.

Sachs then set out guidelines:

a) A sentencing court should find out whether a convicted person is a primary caregiver whenever there are indications that this might be so.

b) A probation officer's report is not necessary to determine this in each case

c) If on the Zinn triad approach the appropriate sentence is clearly custodial and the convicted person is a primary caregiver, the court must apply its mind to whether it is necessary to take steps to ensure that the children will be adequately cared for while the caregiver is incarcerated. 
d) If the appropriate sentence is clearly non-custodial, the court must determine the appropriate sentence, bearing in mind the interests of the children.

e) Finally, if there is a range of appropriate sentences on the Zinn approach the court must use the paramountcy principle concerning the interests of the child as an important guide in deciding which sentence to impose.

He noted that a balancing exercise has to be undertaken on a case-by-case basis, balancing the importance of maintaining the integrity of family care with the duty on the State to punish criminal misconduct.

"The paramountcy principle, read with the right to family care, requires that the interests of children who stand to be affected receive due consideration. It does not necessitate overriding all other considerations. Rather, it calls for appropriate weight to be given in each case to a consideration to which the law attached the highest value, namely the interests of children who may be concerned." (p.26)

Sachs pointed out that the question put to $\mathrm{M}$ by the Regional Magistrate and the prosecution at her trial, that of whether if she went to prison her children would be on the street, was inadequate and that this meant that sentence was passed without sufficient independent and informed attention as required by section 28. The Constitutional Court decided that it could reconsider the sentence. In doing this the court had to balance the fact that she had defrauded members of the community three times and over a period of years and had offended while serving a suspended sentence and later on bail, with the fact that she had spent seven years developing a lawful and legitimate community business and she was a good 
parent in relation to her children. She had also offered to pay back the amount defrauded in monthly instalments.

The court concluded that as the offences were deliberate and involving deception, the sentence of four years' imprisonment should stand. She had already spent three months in prison, one awaiting trial and two after the sentence was imposed. Sachs concluded that the sentence already served should be backdated and the rest should be suspended so she need not go back to prison, and a correctional supervision order should be added on. He explained that he was influenced by the reports which indicated that it was clearly in the interests of the children if they continued to receive primary care from their mother:

"despite the bad example $M$ has set, she is in a better position than anyone else to see to it that the children continue with their schooling and resist the pressures and temptations that would be intensified by the deprivation of her care in a socially fragile environment" (p.44).

It is important to realise that the impact on the children was not decisive on its own; rather, in conjunction with her offer to repay the persons defrauded, the fact that she had behaved lawfully for seven years, and the fact that she had "manifested a will to conduct herself correctly." She thus, in conjunction with the suspended sentence, was ordered to be under correctional supervision for three years, performing ten hours per week of service of benefit to the community, also undergoing counselling as appropriate and repaying to those defrauded an amount equal to the value of the goods obtained. Six judges agreed with Sachs and three judges dissented.

The case is significant as it demonstrates a 'changed mind-set' in sentencing caregivers, and allowing the rights of children affected by sentencing decisions to be introduced into the decision-making process (Donson \& Parkes, 2016). The principles set out in $S \vee M$ were 
followed by the same court subsequently in S (2011 (7) BCLR 740 (CC) where the court held that a co-parent was available to care for the children, although the dissenting judgment of Khampepe $J$ in this case is significant, in that she argued that insufficient consideration had been given to the quality of alternative care which could be provided by the husband and that justice could be served just as effectively by ordering correctional supervision with appropriate conditions attached: as Skelton (2011) has argued, "if the possible imprisonment will be detrimental to the child, then the scales must tip in favour of a non-custodial sentence, unless the case is so serious that it would be entirely inappropriate". Reported cases since the decision in $\mathrm{S} \vee \mathrm{M}$ have indicated that there has been some progress in altering the mindset of sentencing courts in South Africa, Carnelley \& Epstein, (2012)highlighting that in the lower courts these guidelines have been followed consistently prior to sentencing- while it has not always meant that non-custodial sentences have been handed down, the courts have become 'sensitised' to the needs of children when sentencing the primary caregiver. This case has prompted discussion and debate around law, policy and practice in several countries outside South Africa, as seen in Scotland where Albie Sachs himself delivered several influential presentations and prompted discussion by the Scottish Sentencing Council and invited expert participants (Scottish Sentencing Council 2017).

\section{The Rights of Children Inside and Outside the Prison}

One of the thorniest dilemmas concerning the rights of children whose parents are incarcerated relates to babies and children who are either born while the mother is in prison, or who accompany their mother into the prison while the sentence is served. Much of the published research literature focuses on mothers and children who are separated by reason of a prison sentence, especially that from the US, Europe and Australia \& New Zealand 
(Scharff-Smith \& Gampell (eds.) 2011: Celinska \& Siegel , 2010: Bernstein 2005). In contrast, however, in many countries in the word babies and children live with their mothers in prison, with wide variation in their experiences. Just as the dominant view in the literature from the 'West' is of mothers mothering from the inside, the dominant view in the rest of the world is of mothers mothering on the inside. This dominant focus on mothers, rather than fathers or other caregivers, has been criticised but most specific residential facilities in prisons are aimed at mothers, with an exception being the the family units in Aranjuez Prison, Spain, where imprisoned mothers and fathers can live together with their children aged up to three years' old (Paurus, 2017).

The CRC has paid particular attention to the challenges of identifying the best interests of children in this context, the core question being whether the best interests of the child are best served by either allowing the child to live with their mother in the prison, or whether the child's best interests are served by separating the mother from the child, the child living with other family, kin or friends, or within the state care system. In the US, this focus on long-term stability for children led to the controversial provisions of the Adoption and Safe Families Act 1997, which, by stressing 'permanency planning', led to many imprisoned parents experiencing the termination of their parental rights entirely, their children being freed for adoption. The UN has emphasised that the birth of babies in prison, or by prisoners, should be avoided throught the use of non-custodial alternatives to incarceration for pregnant women, and that similarly non-custodial penalties should be used where possible in order to prevent separation of mothers and children. The benefits for babies and children are that a baby can continue to be breastfed, bond with the mother and develop a strong attachment relationship. The disadvantages include the physical and environmental inadequacy and limitations of the prison setting; potential dangers posed by other inmates, and 
institutionalisation. That said, there are many examples of prison nurseries, mother and baby units, and half-way houses, in which babies and children can spend varying amounts of time with their mothers, and examples of child-focused visitation and contact arrangements which mean that although the child lives outside the prison they are able to develop and maintain strong relationships with their imprisoned parent (Codd, 2013: Paurus, 2017).

Many of the arguments in favour of facilitating children to live in prison with their mothers draw on psychological theories of bonding and attachment. However, in many parts of the world the social and economic situation of the mother, combined with a lack of state childcare and child protection provision, may mean that if the child is not allowed to remain with the mother then the child may be at risk not just of psychological harm but also starvation; neglect; abuse; exploitation and death (The Law Library of Congress Global Legal Research Centre 2014: Tibatemwa-Ekirikubinza 1999: Henry-Lee 2005: Bharucha 2007). Babies and children may share the same beds as their mothers, share their food, and not have access to healthcare or education, but in the simplest terms it is still better for them to stay with their mother than to be separated. In countries which have considered this issue in children's rights terms, this is not an easy decision, and when the child is sufficiently able to form a view, that view must be heard, under the CRC. Increasingly, research has emerged which compares policies and provisions from different jurisdictions, a common complaint being that children living in prison with a parent are too often ignored, leading to their needs and best interests being unrecognised and unmet (Enroos, 2015: Robertson, 2008: Alejos 2005: Rosenberg 2009). This research demonstrates that children's rights are often not considered, and that even when the best interests test is recognised it is difficult to determine what is in a child's best interests in a particular context or culture (James \& James, 2004). 


\section{IV: Conclusion}

The rights of prisoners' children in many countries are, arguably, unenforceable and thus illusory without specific legislation enshrining CRC rights within domestic law, and without a written constitution, bill of rights and supporting case law, as exemplified in South Africa. There is a strong case for arguing that rights-based approaches are inadequate and flawed in this context, as it could be argued that although children's rights appear to be guaranteed in a range of treaties, rights discourse has ultimately failed to promote and protect children's well-being, as Posner (Posner 2014) has highlighted in the context of international human rights law as a whole. That said, as Fortin (2014) points out, there has been a serious commitment in the UK, led by Baroness Hale, that all public agencies must consider children's best interests as a primary consideration when they reach decisions which affect children, either directly or indirectly. This has meant, for example, that the immigration law decision in ZH (Tanzania) v Secretary of State for the Home Department [2011] UKSC 4 was referred to in the case of $R(M P)$ v Secretary of State for Justice [2012] EWHC 214 (Admin), in which it was held that the prison authorities were obliged to interpret Article 3 of the CRC in relation to the availability of Childcare Resettlement Leave in the light of that provision, even if it was not enshrined in primary legislation.

The $M$ case, and subsequent cases in South Africa, could be held to be of limited relevance to other jurisdictions, as the South African Constitution itself provides a very strong statement as to the paramountcy of children's rights, reflecting the African Charter on the Rights and Welfare of the Child. . In addition, the $M$ case engaged highly qualified and senior members of the judiciary, including Albie Sachs, in explaining the nature, grounds and justifications for rethinking the sentencing decision-making process when sentencing parents with dependent 
children. This case illustrates well, however, the potential for judicial leadership so as to make children's rights a paramount consideration.

Provision for, and consideration of, the needs of children of incarcerated parents has been more often interpreted as a function of social work, or as a means of maintaining family relationships in order to promote desistance than as a significant question of children's rights. However, there are some inspiring examples of child-focused practice. In Sweden, Denmark and Norway, Children's Officers have been created. These are prison staff, who are responsible for 'anchoring' a children's rights perspective in their institution with regard to prisoners' children (Scharff Smith 2015), this role including issues of visits and child-centred events. That said, in his account of the situation in Scandinavian penal cultures, Scharff Smith asserts that there is still a long way to go towards making sure that children's rights are always taken into account, and he calls for concrete national standards with regard to issues such as child-friendly visiting conditions and practices. He stresses the importance of making sure that children's rights, when applied to prisoners' children, are not just abstract principles but "actual legal rights with practical implications" (p.168). In 2014 in Italy, a Memorandum of Understanding was signed which brought together the main Italian NGO working with children of prisoners (Bambinisenzasbarre); the Minister for Justice and the National Ombudsman for Childhood and Adolescence. This MOU related to the fulfilment and protection of the rights of children of imprisoned parents, and this was renewed in 2016. Article 1 of the Memorandum covers judicial decisions, where judicial authorities are encouraged to take into account the rights and needs of any underage children of an arrested or detained person who still has parental responsibility; giving priority to alternative measures to pre-trial detention. Authorities are required to provide contact between a pretrial detainee and their child in respect of the child's rights. In addition the Memorandum 
includes the recommendations made by the Children of Prisoners Europe (COPE) network with regards to visiting conditions and provisions for children of imprisoned parents, and also the location of the prison in order to guarantee direct contact between children and their parents. This Memorandum signals a joint, combined commitment to the rights of prisoners' children, informed by research.

If we look at situations when prisoners' children interact with the family justice system then we see situations where they are recognised as vulnerable and where their interests are recognised and prioritised, as in decision-making after parental relationship breakdown or during local authority care proceedings. Interestingly, in residence and contact cases following parental relationship breakdown they are not the primary parties involved in the case, as the primary parties are the separating or divorcing parents. However, their needs and benefit are of fundamental importance. In contrast, when parental sentencing decisions are concerned they are not accorded the same importance or standing. A number of arguments have been put forward in relation to mechanisms for challenging the binary focus of the adversarial criminal trial, as exists in countries including the UK, Ireland and the US. Courts in many jurisdictions already receive additional information in the form of specialist reports, such as in Pre-Sentence Reports in England \& Wales, and a number of commentators have argued for Child Impact Statements to become a compulsory requirement in cases where the offender is responsible for children. However, although this would seem to offer a potential for including and recognising the impact on children, the simple presentation of a report is not sufficient to guarantee a particular outcome, especially if the application of the information in the report is interpreted as discretionary rather than mandatory. 
To conclude, the provisions under the UNCRC are wide enough in scope to include the children of prisoners. However, the Convention lacks integral mechanisms for translating paper rights into practice, so the rights remain aspirational and are only concrete and actual if a state makes that happen. The existence of a legal right is, of course, no guarantee that those rights will translate into actual policies, or be enforceable at the grassroots level. It has been argued, for example that concepts of children's rights do not lead automatically to better outcomes for children, and that a 'best interests' or approaches based on duties may be more valuable (Ferguson, 2013). The 'paper tiger' of the CRC itself means that these rights, while existing on paper, may become 'theoretical and illusory' in real life, and as Jane Fortin has argued eloquently "it takes a very unusual child to come forward and make claims of this kind" (p.53). This issue is of course not new, nor restricted to children: in many penal systems rights which exist on paper are unenforceable in practice, as demonstrated by research in India by Kaushik and others (Kaushik \& Sharma, 2009: Kaushik, 2010) where legislative protections of women prisoners' rights were of no practical value because women were unable to challenge agencies in authority, due to fear of the prison guards and poor literacy. The other issue is that of vulnerability: the apparent burden of rights claims falls on those who are victimised and vulnerable, although this situation could be improved if all decisions of public bodies have to comply with the provisions of the CRC or similar from the outset, preempting complaints after the event. Children need access to justice, including information on potential remedies, and should be supported or assisted in accessing justice mechanisms, which are tailored to the needs of individual children and, for young children, could include the appointment of a guardian ad litem or similar person responsible for ensuring their views are heard by the court (Liefaard 2015). There is no doubt that the children of imprisoned parents posses legal rights: the challenge is to ensure that these rights translate into real-life 
laws, policies and practices which put children and their wellbeing at the heart of penal decision-making.

\section{References}

Alejos, M. 2005. Babies and Small Children Residing in Prisons. Geneva: The Quaker United Nations Office.

Alston, P. \& Tobin, J. 2005. Laying the Foundations for Children's Rights. Florence: UNICEF Innocenti Research Centre.

Bernstein, N. 2005. All Alone in the World: Children of the Incarcerated. New York: The New Press.

Bharucha, R.N. 2007. Shadows in Cages: Forgotten Women and Children in India's Prisons, Honesdale, PA,. Honesdale PA.: Himalayan Institute Press.

Boudin, C. 2011. "Children of Incarcerated Parents: The Child's Constitutional Right to the Family Relationship." The Journal of Criminal Law \& Criminology 101 (1): 77-118.

Carnelley, M. \& Epstein, C.A. 2012. "Do not visit the sins of the parents upon their children: Sentencing Considerations of the primary caregiver should focuis on the long-term best interests of the child." South African Journal of Criminal Justice 25: 106-116.

Celinska, C. \& Siegel, J..A,. 2010. "Mothers in Trouble: Coping with Actual or Pending Separaton from Children due to Incarceration." The Prison Journal 447-474.

Child, United Nations Committee on the Rights of the. 2011. Report and Recommendations of the Day of General Discussion on "Children of Incarcerated Parents". Geneva: UNCRC.

Codd, H. 2013. "Locked in and Locked Out: Global Feminist Perspectives on Women and Imprisonment." In Global Criminology: Crime and Victimization in the Globalized Era, by K Jaishankar and N Ronel, 199-. Boca Raton, FL.: CRC Press: Taylor \& FRancis Group. 
Donson, F. \& Parkes, A. 2016. "Weighing in the Balance: Reflections on the Sentencing Process from a Children's Rights Perspective." Probation Journal 63 (3): 331-346.

Enroos, R. 2015. "From Invisibility to Protection - Children in Prison with their Parent in Finland." Children \& Society 29: 399-409.

Epstein, R. 2014. "Mothers in Prison: The Sentencing of Mothers and the Rights of the Chjild." Working Paper 3/2014 (Howard League).

Ferguson, L. n.d. "The Jurisprudence of Making Decisions Affecting Children: An Argument to Prefer Duty to Children's Rights and Welfare."

Ferguson, L. 2013. "Not Merely Rights for Children But Children's Rights: The Theory Gap and the Assumption of the Importance of Children's Rights." International Journal of Children's Rights 21: 177-208.

Fortin, J. 2014. "Children's Rights - flattering to deceive?" Child and Family Law Quarterly 26 (1): 5162.

Henry-Lee, A. 2005. Women in Prison: The Impact of the Incarceration of Jamaican Women on Themselves and their Families, . Kingston: The Planning Institute of Jamaica Social Development and Gender Unit.

Her Majesty's Chief Inspector of Prison. 2016. Report on an unannounced inspection of HMP/YOI Parc. London: Her Majesty's Inspectorate of Prison.

Kanaboshi, N., Anderson, J.F. \& Sira,N. 2017. "Constitutional Rights of Infants and Toddlers to Have Opportunities to Form Secure Attachment with Incarcerated Mothers: Importance of Prison Nurseries." International Journal of Social Science Studies 5 (2).

Kaushik, A. and Sharma, K. . 2009. "'Human Rights of Women Prisoners in India: A Case Study of Jaipur Central Prison for Women',." Indian Journal of Gender Studies 16: 253-271.

Kaushik, A. 2010. Human Rights of Women Prisoners in India: A Case Study of Varanasi District Prison. Koeln,: LAP Lambert Academic Publishing.

Liefaard, T. 2015. "Rights of children of incarcerated parents: towards." European Journal of Parental Incarceration.

Millar, H \& Dandurand, Y. 2017. "The Best Interests of the Child and the Sentencing of Offenders with Parental Responsibilities." https://doi.org/10.1007/s10609-017-9340-9.

Minson, S. Nadin, R. \& Earle, J. 2015. Sentencing of mothers: Improving the sentencing process and outcomes for women with dependent children. London: Prison Reform Trust.

Minson, S., and R \& Condry. 2015. "The Visibility of Children whose Mothers are Being Sentenced for Criminal Offences in the Courts of England and Wales." Law in Context: A Socio-Legal Journal 32: $28-45$.

Pandey, S.P. \& Singh, A. . 2006. Women Prisoners and their Dependent Children (The Report of the Project Funded by Planning Commission, Government of India, New Delhi). New Delhi: Serials Publication.

Partnership, Children of Incarcerated Parents. 2003. Children of Incarcerated Parents: A Bill of Rights. San Francisco. San Francisco: Children of Incarcerated Parents Partnership. 
Paurus, M. 2017 (?). International Report on the Conditions of Children of Incarcerated Parents: A Study of Prison Nurseries. Minneapolis: Children of Incarcerated Caregivers.

Philbrick, K., Ayre, L. \& Lynn, H. 2014. Children of Imprisoned Parents: European Perspectives on Good Practce. 2nd Edition. Paris: Children of Prisoners Europe.

Robertson, O. 2012. Robertson, Oliver. Collateral Convicts: Children of Incarcerated Parents, Recommendations and Good Practice from the UN Committee on the Rights of the Child Day of General Discussion 2011. . Geneva: The Quaker United Nations Office.

Robertson, O. 2007. The impact of parental imprisonment on children. Geneva: Quaker United Nations Officd.

n.d. Salvador Declaration on Comprehensive Strategies for Global Challenges: Crime Prevention and Criminal Justice Systems and their Development in a Changing World.

San Francisco Partnership for Incarcerated Parents. 2003. Children of Incarcerated Parents: A Bill of Rights. San Francisco.

Scharff Smith, P. 2015. "Children of Imprisoned Parents in Scandinavia: Their Problems, Treatment and the Role of Scandinavian Penal Culture." Law in Context 32: 147-168.

Scharff-Smith, P. and L. Gampell (eds.). 2011. Children of imprisoned parents,. Denmark: Danish Institute for Human Rights, European Network for Children of Imprisoned Parents, University of Ulster and Bambinisenzasbarre.

Scottish Sentencing Council. 2017. "Children and the sentencing of parents: report on discussion event with Scottish Sentencing Council." Edinburgh 6th March.

Skelton, A. 2011. "'Children of Incarcerated Parents' at the CRC Day of General Discussion 2011." Accessed January 3rd, 2012.

http://www2.ohchr.org/english/bodies/crc/docs/Discussion2011_submissions/A_SKELTON_ CRC_DGD_2011.pdf.

Skelton, A. 2015. "South Africa." In Litigating the Rights of the Child, by T.Liefaard \& J.E. Doek (eds.), 13-30. Dordrecht: Springer.

The Law Library of Congress Global Legal Research Centre. 2014. Laws on Children Residing with Parents in Prison. Washington DC: The Law Library of Congress.

Tibatemwa-Ekirikubinza, L. 1999. Women's Violent Crime In Uganda. More Sinned Against Than Sinning. Uganda: Fountain Publishers.

Townhead, L. 2015. Briefing Paper: Children of Incarcerated Parents - International Standards and Guidance. Geneva: Quaker United Nations Office.

United Nations Model Strategies and Practical Measures on the Elimination of Violence against Children in the Field of Crime Prevention and Criminal Justice. n.d. E/CN.15/2014/L.12/Rev.1 of 15 May 2015, para 6(c)

van Zyl Smit, D. \& Snacken, S. 2009. Principles of European Prison Law and Policy. Oxford: Oxford University Press.

Vetten, L. 2008. "The Imprisonment of Women in Africa." In Human Rights in African Prisons, by J. (ed.) Sarkin, 134-154. Cape Town: HSRC Press. 
${ }^{\mathrm{i}}$ QUNO has also compiled a database of relevant recommendations from the CRC in relation to children of imprisoned parents - see www.crccip.com

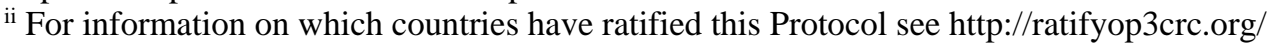

